\title{
Post-imperial imaginaries in Zimbabwe: Interrogating betrayal in the pre- and post-war years in Chinodya's Harvest of Thorns and Child of War
}

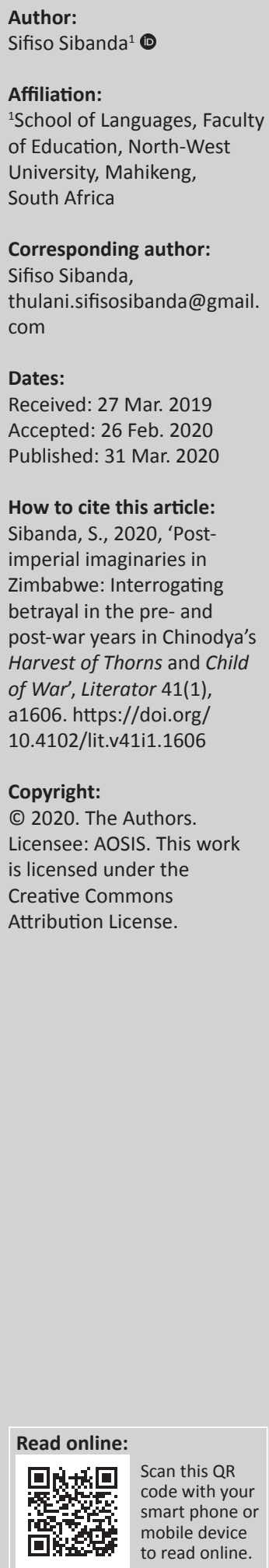

Shimmer Chinodya's novels, Harvest of Thorns and Child of War, indict betrayal in the postwar years of Zimbabwe. The post-war years had potentially promised an imagined realm where black hegemony would supplant white supremacy to establish black utopia. This article examines the angst that follows the post-imperial betrayal of these ideals in Zimbabwe and evaluates the extent to which this betrayal affected the masses after a hard-won independence. It highlights the extent of despair among war veterans and the masses after their marginalisation on the eve of independence. The article further demonstrates how the transmogrification of youth into pseudo-adults during the years of the struggle and their post-independence abandonment caused untold crises in Zimbabwe, highlighting the inconstancy of post-imperial politics in Zimbabwe and in many other African countries. The literature depicting the years of the struggle and post-independence was consulted extensively to interrogate the ideals of independence and how these have been betrayed. The article contends that the nationalist government only succeeded in dislodging the coloniser and started carving a new repressive state apparatus. Benjamin, in Harvest of Thorns, epitomises the bitterness of the guerrillas who are emasculated and pauperised after fighting for freedom in Zimbabwe. Chinodya's later novels and short stories together with those of his contemporaries from other African countries such as South Africa and Kenya particularly recoil at the intransigence immanent in the new leadership who have marginalised citizens and inaugurated corruption.

Keywords: Harvest of Thorns; neo-colonialism; betrayal; freedom fighters; liberation; independence.

\section{Introduction}

In the novels Harvest of Thorns and Child of War, Shimmer Chinodya traces the betrayal of human ideals, which culminates in the bitter experience of post-colonial Zimbabwe. Like Hove (1988), Vera (2002), Marechera (2009), Mungoshi (1989) and many other dissenting literary voices, he writes of the masses who remain dispossessed and suffer varieties of social ills. His two novels explore the ideological cartography of Zimbabwe after independence with a view to articulating Chinodya's conviction that Zimbabweans have not yet realised their full democratic rights, even after more than three decades of flag independence. Raftopoulos and Mlambo (2011:6) contend that the political and economic furore prompted 'the relocation of Zimbabwean intellectuals to other countries thereby producing a new conjecture in which to rethink the country's history'. In concurrence, Chinodya contends that the collapse of the dream for a better future after independence has created a longing for possibilities that remain far too remote to achieve. This view is shared by Mungoshi (1989), whose main character in Waiting for the Rain, Lucifer, finds home a nauseating and incompatible habitat and Hove (1988) whose Marita in his novel, Bones, suffers 'the bureaucratic insensitivity of black government officials' (Veit-Wild 1993:6).

Several other scholars have decried the demise of the dream of democracy and a violence-free state, which became imminent a few years into the country's independence. Norman (2015) contends that:

Mugabe, instead of leading his people to the Promised Land, has on the one hand amassed a fortune for himself, his family and his followers and on the other presided over the deliberate murder, torture, and starvation of those who oppose him. (p. 15)

Moreover, Chan and Primorac (2013:vii) have maintained that 'the decline of Zimbabwe continues to haunt African, Commonwealth and wider international relations'. They seem to have observed 
that since independence, Zimbabwe's economy and politics are deteriorating to alarming levels.

The post-war years have been marked by spurts of violence and intolerance by the governing party. There has been a tendency to perpetuate the legacy of the battlefield politics. For this and a host of other issues, 'the emotional asset base of Robert Mugabe's power is warehoused in bitter remembrance of victimhood' (Muponde in Raftopoulos \& Savage 2004:178). The amount of pressure exerted from the West to address abuses of human rights and civil freedoms in Zimbabwe has been severely compromised by reminders of the role of Western states, precisely Britain, in plundering the country through imperial subjugation, foreign rule and postcolonial influence (Villa-Vicencio in Raftopoulos \& Savage 2004:v). The degeneration to violence as a means of solving political differences remains a critical emblem of aborted post-independence promises. Various versions of compulsion and repression have since increased to the point of international concern. This could be partly explained by the dictatorial style of leadership that the Mugabe regime rapidly implemented immediately after independence (Sachikonye in Raftopoulos \& Savage 2004).

$[I] \mathrm{t}$ is a matter of great concern that the tens of thousands of Zimbabweans who have suffered torture and other violations at the hands of the state and its agents are not further abused in the future. (p. 53)

The pitiable situation of squatters reflects the unrelenting distress of the multitudes in Zimbabwe after liberation (Mupondi 2013).

The worst recipients of undelivered promises are the war veterans. Their plight has contributed significantly to the shaping of the country's post-war outlook. The ruling party has used the veterans to consolidate state power (Kriger, in Darnolf \& Laaksol 2003). The lack of a comprehensive approach to the integration of war veterans has created both a festering problem for the state and a ready source for mobilisation of a state in crisis (Raftopoulos, in Raftopoulos \& Savage 2004). Their barely audible voices in this period should not be equated with their powerlessness because they did not always have an organisation (Kriger, in Darnolf \& Laaksol 2003:105). For this reason, they find themselves in a similar predicament with the rest of the disillusioned masses, 'even the war veterans who fought in the struggle for independence are now being dispossessed of their lands' (Norman 2015:15). The disregarding of war veterans flags discontentment that is echoed by Chinodya in his two works, Harvest of Thorns and Child of War. According to the brief literature review above, it is evident that there is a dearth of literature regarding Chinodya's two selected works. Nevertheless, this article is written with the view to alleviating this scarcity.

In Harvest of Thorns, Chinodya reveals his animus that triggers Zimbabwe's governance challenges and the state's ingratitude towards the war veterans for their contribution to independence through insurrection. Chinodya's tragic hero, Benjamin, endures total indigence. Through Shamiso, Benjamin's mother,
Chinodya shows how the role of the war veterans was downplayed. According to her, engaging in the armed struggle has been a sheer waste of time. She aggravates Benjamin's predicament when she says, 'Look at your friends who finished school and started working. You'll never catch up with them!' (Chinodya 1989:24). Benjamin is compared with his contemporaries who did not join the liberation struggle, but who now possess big houses and live lavishly. Benjamin and his ilk are further alienated from their communities because they bear the stigma of being killers during the bush war. The same sentiments are voiced by distraught South African military veterans in Zakes Mda's (2000) The Heart of Redness:

'Everything now ... the fruits of liberation ... are enjoyed only by those from exile or from Robben Island,' he overhears a man from the group of dagga-smokers complain. 'Yet we were the ones who bore the brunt of the bullets. We threw stones and danced the freedom dance.' 'Yes, while they were having a good time overseas we were dying here. We were cannon fodder for those who are eating softly,' adds another. (pp. 34-35)

This citation captures a group of military veterans who are at a night vigil for a late acquaintance in Hillbrow, Johannesburg. From their tone, it is evident that they are dissatisfied with the way they are living; they have to smoke dagga to pass the time and soothe their wrecked nerves. Sometimes these fractured individuals are mistaken for rogues, yet they represent the real casualties of an unappreciative government. Ideally, these men should have been properly documented and accorded their rightful status as freedom cadres. Disgruntled voices of this nature are common across most African countries. When the war of liberation ended, the military veterans who comprised those who were at the forefront, dodging bullets, were completely forgotten by the new governments whose primary aim turns out to be personal enrichment.

In Chinodya's view, this perpetuates suffering among the freedom fighters as they are marginalised by the very people for whose freedom they fought. Chinodya highlights the plight of the war veterans, by using various images of their suffering during and after the war, but unfortunately the freedom fighters have since been forgotten because their role of liberating the country is over; they have to be content with the crumbs that they pick from garbage bins. Vera's The Stone Virgins represents a twist to some of the post-war guerrillas' experiences. From the perspective of Driver and Samuelson (2007):

As a Zipra soldier, Sibaso is not remembered and honoured as a freedom fighter by the ruling group. He believes that despite his participation in the brutally taxing Liberation War he has been sacrificed by the new political order. Steeped in death and violence through the Liberation War, and himself a creature of violation and abuse at the hands of his treacherous fellow Zimbabweans, Sibaso becomes a rapist and murderer. (p. 107)

Sibaso refuses to be integrated into the new system and thus is labelled a dissident. The disidentification of the guerrillas introduces a wholesale of massacres of innocent civilians in Matabeleland. Vera recounts the brutal nature of repression 
that the nationalist government exerts on innocent lives. This uncommon commonwealth baffles the innocent citizens of Matabeleland whose post-war imaginaries had been bliss.

Upon his return from the war, Benjamin is told that he does not qualify for demobilisation payment. This baffles the reader because Benjamin's documents are in the file, yet he is still dismissed after threats that his claim is fraudulent. Through this narrative, Chinodya further heightens the plight of Benjamin and his ilk, who are now labelled 'war veterans', by graphically explaining the nature of the advertisements for current jobs, pushed far beyond the competencies and skills of the war veterans: 'The jobs advertised in big letters were for managers and accountants and directors and the ones in very small print were for mechanics, engineers, secretaries and the like' (Chinodya 1989:15). The reader is surprised that when Benjamin arrives at the demobilisation office, and he is interrogated by people who manage to obtain all the answers and reasonable proof that he is a genuine freedom fighter, but they still dismiss him. The officer actually confirms Benjamin's claims when he says:

[Y]ou see, comrade, we're having trouble with people who are coming forward claiming they were combatants when they were civilians. The army has already lost thousands of dollars paying out these false claims. (Chinodya 1989:16)

To worsen Benjamin's plight, the officer advises:

Even if your papers were in order, that would take time. The recruiting officer has a long waiting list. They are taking people with special skills first. Mechanics and so on. What certificates do you have? (Chinodya 1989:16)

The irony here rests on the fact that most of the war veterans are school 'drop-outs', making it highly unlikely that they possess any special skills or any recognised academic qualifications. In this instance, Chinodya is dismayed and criticises the government for being insensitive in dealing with the war veterans. At this stage in the young country, very few people have had a decent education because the war ensured that schools and most of the colonialist service points were totally shut down. Education was a symbol of white colonisation; hence, the closure of schools, especially in rural areas, was a deliberate disruption of these sites as a menace. It should be borne in mind that the guerrilla war necessitated the destruction of various amenities, including those that would be used in the emancipated country. There was very little consideration of the future needs of the young democracy that was being so painfully brought to birth through the struggle. It is therefore sarcastic that immediately after the war, veterans who were directly responsible for closing, and in some cases even burning schools, are required to produce evidence of their education to find employment. It is as if they are now being punished for some of their heroic acts during the insurrection.

The closure of some schools in certain rural communities is responsible for inequalities that exist even to this day. The rural people who bore the brunt of liberating the country were left behind in terms of education because their schools were closed, and there was no way of getting educated to meet the needs of the country at independence. The remoteness of the rural communities also denied them access to knowledge on how to skip the country to receive education abroad. Getting education abroad therefore remained a privilege to those who were urban residents. On their return to the country after independence, they were greeted with conspicuous euphoria and seemingly relentless joys and prosperities. Examples of such characters are Simon in Olley Maruma's Coming Home and Mazorodze's Alexio in Silent Journey from the East. However, this contradicts sharply with Camagu's experiences in Mda's The Heart of Redness. When he returns at independence from studying abroad, Camagu is treated with suspicion and is ostracised wherever he goes.

In Chinodya's Harvest of Thorns, Benjamin's plight will apparently be inherited by his new-born baby boy. This child is born to parents who cannot be gainfully employed as a result of their lack of skills. The birth of this child undoubtedly confirms that the poverty in Benjamin's home will carry on through the child. In his e-mail to me, Chinodya contends:

As for the guerrillas and the job market - isn't that obvious? I think there is a lot more to it than getting jobs - fractured lives and futures, emotional scars, and a wounded national conscience. (Chinodya, S., 2012, 'The reasons behind the pen-name Ben Chirasha', email, 31 August, shimmerchi2000@yahoo.com)

His unconcealed feeling is that those who chose to fight wholeheartedly will have to wallow in poverty.

\section{Landmarks of betrayal}

Two crucial areas of concern after independence have been unemployment and the unequal distribution of land. In a paper that he presented at the University of KwaZulu-Natal in September 2005, Mhanda (2005), a former Zimbabwean freedom fighter, argues that:

[T] he misguided and parochial position adopted by the nationalists set the stage for the subsequent unprincipled compromise and betrayal of the ideals of the national liberation struggle and the aspirations of the African people for selfdetermination at Lancaster House in 1979. Britain could not have wished for a better outcome as it ensured the entrenchment of its imperial interests in Zimbabwe ... (n.p.)

Mhanda contends that the attainment of power was an end in itself for many African nationalists. Once in power, they did not bother to undo the state apparatuses that were designed to serve the interests of the former colonial regime. Otherwise stated, Mhanda argues that the African nationalists became neo-colonialist 'watch-dogs' for their imperialist masters in European countries. Mhanda's view confirms Benjamin's in the last chapter of Harvest of Thorns when he finally opens his heart to Dickson, his sister's husband:

We won the war, yes, but it's foolish to start talking about victory. All this talk about free schools and free medical treatment and minimum wages is just a start. The real battle will take a long, long time; it may never even begin. (Chinodya 1989:272) 
Benjamin acknowledges that they may have attained political power, but nothing has changed. The only change is that political power has been appropriated by African nationalists, although the white settler minority still clings to economic power. In concurrence with Benjamin's plight and that of the entire underprivileged groups in the country, Raftopoulos (1994) has argued that:

Among the many paradoxes of the Lancaster House Settlement in Zimbabwe is that, even as the agreement formally ended settler colonial rule in the country, it provided the framework for continued white privilege, on the bases of persistent control of the economy by this elite, and through them, transnational capital. (p. 1)

Contrary to the objectives of the nationalist struggle, independence brings despair to the expectant Africans whose role in the struggle was not limited to jettisoning white minority rule. Benjamin and Hove's Marita are disillusioned and perceive, with great sadness, the entrenchment of neocolonialism and the reprehensible inability of the nationalists to disentangle themselves from the influence of the former colonists.

Kamurai Mudzingwa comments, after reading one short story, 'Queues', by Chinodya, which he wrote after Harvest of Thorns and Child of War:

Shimmer Chinodya ... traces the socio-economic and political deterioration of Zimbabwe in his story, 'Queues'. The unending queues become the symbol of shortages and the epitome of the downturn of the economy. (Mudzingwa 2003:272)

The concerns that Chinodya raises in 'Queues' begin in Harvest of Thorns where he assesses the post-war period and highlights its economic problems. Benjamin's observation that 'nothing has changed and that the real battle has not yet begun', or may never begin, corresponds with the concerns raised by Hochbruck (1994), Mudzingwa (2003), Gunner (1991), Mhanda (2005) Marechera (2009) and many other critical writers. In his talk with Dickson in the beer garden, Benjamin is sceptical about winning the battle. He is fully aware that free education is not all that they fought for (Chinodya 1989:272). Unlike Hondo, Benjamin is mature enough to understand the essence of the struggle. In fact, even the free education that is mentioned does not remain free for long. Hardly a decade after independence (Chung 2006):

[F]ees were introduced for hospital and clinic services: as a result the poorer half of the population could no longer enjoy even the most rudimentary of medical services. In the education sector, I managed as minister to stop the introduction of primary school fees in rural areas where 70 per cent of the population lived, but they were introduced in the urban areas: (p. 266)

Fay Chung, an ex-combatant herself, explains that the benefits of independence were short-lived mainly because the Zimbabwean economy still remained under the control of the former oppressors and their donors. A similar view is maintained by Hendricks, Ntsebeza and Helliker (2013) who argue that:
[T] he very bases of colonialism and apartheid remain intact, since racialized inequalities in both access to and ownership of land persist in the present. With state driven attempts at land having failed to meet even their own modest targets, a fundamental change in approach is clearly necessary... (p. 1)

White people's attitudes towards the economy are sharply epitomised when Benjamin goes shopping with his wife, Nkazana, and his young brother, Peter. The young white cashier does not believe that Benjamin has enough money to pay for all the groceries in the three trolleys that they present at the till. The altercation that ensues underscores Benjamin's dismay at the fact that life has not changed; black people are still expected to be poor and not to buy groceries of that quantity (Chinodya 1989:9). Benjamin battles for recognition as a former freedom fighter, but he is judged according to the clothes that he is wearing, and is downgraded to the ranks of a hobo. His wife, Nkazana, hints that the colonists learnt nothing from the war. The young couple is driven to despair when they realise this stasis. It is after Benjamin has been around his home town for several months that he acknowledges:

[O]f course, when we went out we thought our guns would change things overnight. And then we came back to find the whites could still shout at us because they still have the money and the ex-combatants have to scrounge for jobs like everyone else. (Chinodya 1989:272)

Randolph (1985) cites the then Prime Minister of Zimbabwe, Robert Mugabe, immediately after independence expressing the same sentiments as Chinodya's Benjamin:

In Lagos in December 1980, Mr Mugabe had said that the economy was still being controlled and manipulated by those who had been dislodged from political power, 'They retain the reins of our economy and continue to manipulate it; they seek to invest in our economy in a manner intended to bring about economic control now that they have lost political control. (p. 46)

Mugabe realised after barely a year in office as Prime Minister that the country was still ruled by the colonists because they clung to the economy and could manipulate it. The white minority still controlled the industries, determined the prices of commodities and decided the wages of employees. They still hired and fired employees as they saw fit. Benjamin actually falls victim to their domination:

I worked for a day as a hand at a construction site last month, but when the white foreman heard that I was an ex-combatant I was told that the company had employed too many casual labourers by mistake. (Chinodya 1989:272)

Benjamin is shunned because he is a former freedom fighter, and there is nothing he can do. He is even afraid that within 5 years the war will be forgotten. He finds himself unemployable because he has no educational qualifications, which of course he could not receive when he was fighting. In this way, the war has robbed him of a job that he might have had all this time. The chances of his getting a job seem even dimmer when he reads the advertisement column in the newspaper. 
He flipped to the vacancies section. The jobs advertised in big letters were for managers and accountants and directors and the ones in very small print were for mechanics, engineers, secretaries and the like. He folded the paper neatly and gave it back. (Chinodya 1989:14-15)

When Clopas, Shamiso's husband, eventually comes to meet his son Benjamin after the war of liberation, Chinodya paints a caricature of a man who is, in his own right, a 'petit bourgeois'. Clopas praises his newly acquired car, an old, battered Zephyr Zodiac which ironically betrays his trust by breaking down in spite of the sentiments attached to it. By showing Clopas in this predicament, Chinodya highlights the level of illusion among the elite after independence. The satire extends to the highly idolised dog, Bingo, which feeds on milk, yet the owner is on pension, and can hardly afford milk on a daily basis even for himself. Clopas believes that the departure of white people marks the advent of the 'rich blacks', who should replicate the erstwhile white regime. This is why he struggles to propagate the white culture by inheriting the dog and the car from emigrating white people. Chinodya satirises those black people who envied white people and eventually took it upon themselves to acculturate themselves into pseudo-whites. It is also suggested that these are the same black people who did not participate in the bush war, but at independence they occupied influential positions in the new Zimbabwe. These are those who were named 'omafikizolo ${ }^{1}$ ' because they only emerged when the war was over to enjoy the spoils. The underlying discontent in Chinodya's voice suggests that many people who did not go to the war were quick to loot state resources immediately after independence.

\section{The unsung heroes of the struggle}

Harvest of Thorns was published in 1986, 6 years into the independence of Zimbabwe. About 11 years later, Chinodya published another novel that highlights the plight of a pre- and post-war citizen of Zimbabwe, but this time concentrating on children. A study of the second novel reveals that Chinodya still holds his view of betrayal, which he extends to the youth. In Child of War, the protagonist is Hondo, a child who suffers all the trials of the war of liberation. Through Hondo, Chinodya submits that the scourge of betrayal did not spare the children. He rejects the celebratory stance on independence that other authors have taken.

Reiterating the experiences of betrayal through a child protagonist and rewriting the story of the liberation struggle from the point of view of a child appeal to those readers who did not grasp this notion from the novel Harvest of Thorns. Usually the mere mention of child-soldiers or child abuse attracts attention because of the vulnerability of children. In Child of War, Chinodya underscores the important role played by children in the war of liberation and the government's ingratitude to them. The protagonist, Hondo, is conscripted into the struggle at the tender age of 11 , but he collaborates with guerrillas until the end of the struggle. Most of the sporadic acts of defiance in the novel are staged by young people through organising pungwe $e^{2}$ meetings and playing the roles of mujhibhas ${ }^{3}$ and chimbwidos. ${ }^{4}$ They are very conscious of the consequences of supporting the guerrilla movement, but they are daring enough to remain focused even after the deaths suffered by their friends.

Unlike in Harvest of Thorns, in Child of War the young people take over the baton from their predecessors to perpetuate the Chimurenga..$^{5}$ In Chapter 2 of the novel (Child of War [COW]), Hondo receives a spear from his dying ancestor:

I knew he was dying, the whole valley was full of strange dying men and I was the only living soul in this valley of death but I was reluctant to leave him. At last, I picked up the weapons he had given me and hurried away from that place. (p. 8)

On the critical role played by the children in Chinodya's novels, Muponde and Primorac (2005) write:

Children played a central and active role in the struggle in Zimbabwe and elsewhere in Africa. In Zimbabwe (then Rhodesia), the brutality of the colonial government's armed forces created a great determination on the part of the nationalist guerrillas to fight and change this. (p. 119)

When Hondo takes over from his ancestor, it is assumed that the struggle will continue because of the energy immanent in young people. The task that Hondo accomplishes is far greater than the reward that he receives at the dawn of independence, when he is expected to re-confine himself to the role of childhood. The only reward that Hondo gets is free education that is only ephemeral. Some of his friends are killed, but no compensation is given to their parents. After their enormous contribution, the reader cannot underestimate the involvement of young people in the struggle, but it appears that Chinodya believes that the government has definitely downplayed their role. Even in Harvest of Thorns, one mujhibha meets a terrible death when he is on a guerrillamission from the ammunitions base: 'The mujhibha staggered before them. His hands clawed at his body wildly ripping out strips of bleeding skin [...] The mujhibha, face bathed in blood, fell and was quiet' (Chinodya 1989:244). This young man is accompanying the guerrillas to the ammunition base because he knows the topography very well. The guerrillas use this mujhibha as their global positioning system (GPS) as the young man knows the full cartography of the land. About this mujhibha Chinodya writes:

A mujhibha from the village accompanied them, showing them a route through the farms [...] Beyond the mission school they began the ascent into the bewildering tangle of mist-caped, mystical hills that looked so alike that without the mujhibha they would have spent days going around in circles. An athletic eighteen-year-old with a sombre face, the mujhibha knew the area as he did his own village. He had escorted another group to the 2.War night-vigil.

3.Male young men who ran guerrillas' errands.

4.Young females who cooked, washed clothes and attended night vigils.

5.War of liberation. 
supplies camp before and moved with the sure-footedness of a mountain goat, guiding them through the mists and the showers and great blue whales of rock. (Chinodya 1989:239)

The knowledge that this mujhibha has is undoubtedly invaluable to the efficiency and precision of the bush war. The mujhibha's knowledge is free, although it costs him his life. It is obvious that such deaths were never recognised and repressed in the memories of those freedom fighters who survived the war. At the end of the bush war, no one would mention the likes of this vividly described mujhibha's parents for compensation. In Child of War, Hondo recounts how he and 10 other mujhibhas were deluded and later tortured by the Rhodesian soldiers. As mujhibhas, they had to support the bush war at all costs, but their knowledge of the tactics of guerrilla warfare was sometimes inadequate. When one soldier disguises himself as a guerrilla, Hondo and his friends fall for the trick and are arrested and summarily tortured:

They lit cigarettes and rolled our bodies to sitting position. Then they held the burning cigarettes close to our faces. Hot ashes seared our skins, as they fired a volley of angry questions at us [...] My vision became weaker, weaker, and the burning cigarette stabbed my face, hands, chest, thighs, until my whole body became a tight knot of pain, yelling for release [...] They poured buckets of chilly water over us and left us to lie on the floor in pain. (Chinodya 1989:55-56)

Hondo and his friends have gone through the whole scope of the bush war. Sometimes their suffering transcends that of some guerrillas. This account would definitely categorise Hondo and his friends as true cadres of the struggle, automatically qualifying them for end-of-the-war benefits like the rest of the guerrillas. As Hondo goes on to give an account of the death of some of the young men, the reader is engulfed in the pathos of a parent who will never see his child: 'As we scurried away from the whizzing bullets another of my mates sank down on the grass' (Chirasha 1991:58). Sadly, many youths contributed to the liberation struggle, but were never acknowledged on the day of independence.

There are several young men and women whose names are mentioned in the war. Their sacrificial participation serves as evidence that they contributed immensely to the success of the liberation struggle. Girls are sexually abused and some eventually give birth to children whose fathers they will never identify in the public. Benjamin remembers most of the relationships between young girls and guerrillas. These relationships exist in spite of several warnings that guerrillas must never have sex with civilians:

Before that, he had seen Maritha and Chenzira, Baas Die and Gidi Ishumba's respective girlfriends, sneaking in and out of the base. At first he had not suspected anything and then slowly, it had dawned on him that everyone carried on their faces the furtive looks that said they knew. (Chinodya 1989:230)

Girls play several roles in the liberation struggle, and among those roles is sexually gratifying the guerrillas. Considering the crucial nature of the liberation struggle, girls could not refuse to give pleasure to those who are key players in the war; in fact to them it is a new status and a prestigious role. Even if this is against the rules of the bush war, it apparently serves as the only entertainment for the young guerrillas. Children are born long after these guerrillas have been transferred from their operating zones, or killed. Chinodya suggests that the lives of these young women were fractured beyond repair, more so as the new government turned a blind eye, and focused on looting the state resources. The children who were born greatly increased the numbers of street children that was already a problem even before independence. These are some of the grey areas that Chinodya highlights.

Some of the parents of the young people who were involuntarily conscripted into the war lost their children, but the new government never had time to dress these wounds etched by the war. The reader is amazed that even the women who bore the brunt of the liberation struggle were never compensated, let alone recognised as freedom fighters. Women prepared meals for the guerrillas, and often endangered their lives in this chore. Chinodya undertakes to speak for those whose lives were broken by the bush war, but cannot speak for themselves. These are the same people who continue to be matter, yet their contribution to the liberation is deliberately erased from memory.

The young and elderly folk from the countryside contributed immensely to the struggle. In Child of War Chinodya maintains:

Women and the girls were called upon to cook food for the guerrillas. Every family was asked to contribute money to buy food for the guerrillas, who liked to eat well. Meat was their favourite delicacy - it was not unusual for them to refuse meatless vegetables! Thus villagers' stock of chicken and goats dwindled steadily. (p. 24)

The guerrillas could not cook for themselves either because they did not know how or had no money for food. The onus to ensure that the guerrillas were well fed rested squarely on the villagers. These poor folk had to buy expensive food for the guerrillas. This meant that the villagers were often stripped of their little wealth to the point of total indigence. Having to feed the guerrillas who often ate large quantities of food meant that women had to work full-time to ensure that the guerrillas were well fed. The rural communities contributed immensely to the struggle, sometimes even more than the guerrillas themselves, but in the actual distribution of power, it was the urban leadership that took precedence, in spite of the fact that the urban folk did not contribute as much as the rural.

The big challenge was that at the end of the bush war, the youths were expected to play the role of tractable youngsters after having been entrusted with the responsibility of liberating the country, even though most of the elders who became leaders were in their octogenarian stages, and some already suffering from senility. The exclusion of young people from leadership justified their misdemeanours. They felt left out of the whole leadership structure after their immense contribution. 


\section{Perpetrators of corruption post-independence}

The old people at the head of affairs are often found guilty of social crimes such as nepotism and other forms of corruption. The former minister of Education in Zimbabwe, Chung (2006), describes some of the ordeals that she went through as a Head of Department in the Ministry of Education in the late 1980s, just before she became Minister of Education:

\begin{abstract}
I was very politely requested by my superior officer to promote a young teacher to become an officer in my department. I interviewed the young lady and found her reasonable, but without the requisite experience, so I did not promote her. I was surprised to find that this led to a huge conflict, during which I was accused of not 'following directives'. It turned out that the young lady was the girlfriend of my superior officer. (p. 271)
\end{abstract}

Chung goes on to argue that having spent more than 5 years in the liberation struggle, she would not accept relatives being promoted, especially when they were not suitable for the posts. In 2001 the then Minister of Education, Edmund Garwe, took his life in an unusual case of self-chastisement after his 14-year-old daughter leaked Zimbabwe Junior Certificate examination papers. The papers had been in the Minister's custody when the whole scandal took place (Newsday Zimbabwe 2014):

Garwe knew the enormity of the crime that had been committed and he couldn't stand the shame that would go with it. He knew that the integrity of any education system lies in the way it handles its examination co-ordination. (p. 1)

There was also a scandal about cars, dubbed the 'Willowgate scandal', which rocked the country during its honeymoon days of independence. Several ministers endured public humiliation, and some even took their own lives. Corruption is one of the most dangerous foes of independence. The corruption in Willowvale Motors prompted singers like the late Solomon Skuza, who composed a song entitled Love and Scandal in which he vehemently criticises the corruption of ministers' importing cars - the Toyota Cressida was the most fashionable at the time - very cheaply acquired through Willowvale Motors because of the government subsidy, and reselling them at a profit of 200\%. In his song Skuza (1989) says:

How can someone buy a car and sell it again? Everybody wants to know! Even the povo ${ }^{6}$ wants to know!

I don't know why, I don't know why ... The information has been leaking ...

Mapfumo (2015), a renowned singer, released an album entitled Corruption in 1988 after the Willowvale scandal and other versions of corruption that were prominent during those days:

The 1988 song 'Corruption' officially opens Mapfumo's rift with the regime of Robert Mugabe, turning a government financial scandal into a pop culture sensation. 1999's 'Mamvemve" accuses 6.Poor man on the street.

7.Tatters. leaders of betraying the promises of the liberation struggle and reducing a rich country to 'tatters', and 2003's 'Marima Nzara'8 takes the government on over Zimbabwe's most prolonged and vexing challenge. (Mapfumo 2015:n.p.)

Ever since performing these songs, Mapfumo has been at loggerheads with the Zimbabwean government because they highlight the entrenchment of corruption in the young Zimbabwe.

\section{The decay of Ubuntu and betrayal in post-colonial African states}

Apart from corruption, street urchins who were 'born' with independence flood the streets. Although democratisation of Zimbabwe was envisaged to give birth to a warm country that would look after its orphans whose parents had perished in the liberation war, there still remain even today children whose lineage can only be traced to the streets of Harare, Bulawayo and other towns. One such example is Nkazana, a young girl who eventually becomes Benjamin's wife. There are numerous cases similar to Nkazana's and those who were born in refugee camps. 'In the bush hundreds of girls had babies without anybody knowing' (Chinodya 1989:9). Hundreds of children lost their parents in the bush war. The former minister Chung writes about children who were orphaned in the camps, but at the end of the war had nowhere to go because they could not even trace their relatives. Some of them were those born in the bush (Chung 2006):

I was told by a white official that since these children were 'communists', they should not be allowed to remain together, and that the best strategy was to force them to disperse by not providing them with food [...] The strategy to starve them into dispersal partly worked: those students who could find any relatives left the temporary camps. (p. 275)

This agonistic version of Zimbabwe's 'hospitality' saw a huge rise in the number of children who found streets the only habitat. Contrary to the ideals of Marxism that they preached to the electorate before attaining leadership, the country's leadership developed a capitalist mentality that had characterised the former colonists. The increase in the number of street urchins could have been easily combated through building centres for such children. Even later, after independence, the nationalist leadership exacerbated the problem of street children by introducing school fees. The impoverished and unemployed masses could not afford fees. "This eventually led to the problem of "street kids" without schooling, a problem that had existed in colonial days but had disappeared during the first decade of independence' (Chung 2006:266). In the light of Chung's assertion, and considering the situation on the ground, the nationalist leadership was fully responsible for the street children problem. It went with some of the crises that Benjamin perceives in Harvest of Thorns as constituting an indisputable form of betrayal by the nationalist leadership.

8.You have sown hunger. 
Ngugi's (1987) Matigari shares Chinodya's views in Harvest of Thorns regarding poverty and corruption. In the beginning of the novel, Ngugi portrays stark poverty in his representation of the homeless children, who scavenge for food and other items that they can sell to earn some money. They scramble for food with the dogs, crows and vultures at the dumping sites and brave the weather around the wrecks in which they sleep. The children are dehumanised to the level of scavenging animals. To heighten the plight of the poor, Ngugi compares these children to vermin. Poverty remains one of the major challenges that plague Zimbabwe and many other African countries.

When Chinodya writes his two novels, he etches the young characters so prominently that the reader cannot help but appreciate their contribution to the struggle and then condemn the system of governance for not recognising them. Chinodya (1989), Hove (1988), Vera (2002) and Marechera (2009) have viewed the war veterans, youth and rural folk as pauperised and marginalised. The poor were promised so much bliss and access to resources that the new democracies find difficult to provide because their leaders continue to stuff their bellies at the poor's expense. The promise of democratic equity remains elusive. The promises that were drummed into the peasants' ears at independence are consistently revived every 5 years when canvassing their vote is crucial.

About betrayal, Onyeani (2015), in Roar of the African Lion, argues that most African states blame their former colonisers for the country's economic misfortunes, but he thinks, on the contrary, that African leaders have betrayed their people:

We have despotic leaders who prefer to loot the people's treasuries for their own personal aggrandisement, leaders who prefer to force the adulation of the masses through the barrel of a gun rather than through the provision of simple amenities. (pp. 7-8)

Onyeani contends that African countries still remain poor, and in some cases even worse than they were during the colonial period. Marechera (2009:150) gives credence to this notion when he describes Zimbabwe immediately after its independence as exhibiting 'harsh facts of grim poverty and the struggle's aftermath'. Nevertheless, Onyeani's argument still finds fault with leadership: he heaps all the mishaps on their shoulders, 'African leaders squander people's money in buying palaces in Europe rather than building infrastructure in their countries' (2015:9). In the case of Chinodya's Benjamin, it is possible that the money that was meant to demobilise him and other guerrillas has been misappropriated.

However, Benjamin suffers at the hands of corrupt leaders who claim that he has not been to the struggle and that he might be faking the whole story about the war. Benjamin is explicitly betrayed by the system whose tenets he has fought for and has continued to believe in. This shows the harrowing extent to which corruption has riddled the country at its infancy. Chinodya uses Benjamin's plight to advance his agenda of direct indictment of government failures to mend the fractured lives of guerrillas after the liberation struggle. Benjamin typifies 'discontinuities, reversals, inertias, and swings that overlay one another, interpenetrate one another, and develop one another' (Driver \& Samuelson 2009:101).

\section{Conclusion}

Zimbabwe continues to be entrapped in economic woes that are a result of maladministration, greed, corruption and tribalism, all of which constitute post-imperial imaginaries in Zimbabwe that are stylistically and thematically interrogated in Chinodya's Harvest of Thorns. Betrayal is privileged as a significant trope in this interrogation as this article has demonstrated. The definition of 'liberation hero' has remained elusive as this only gets endorsed at the mercy of the politicians. The war veterans and the civilians whose lives were fractured by the war of liberation have joined the ranks of the pauperised marginalised poor on the rest of the continent. It is therefore befitting that Chinodya insists on a narrative that questions all the independence ideals that have been betrayed, a narrative that chastises independence as some mimic Harvest of Thorns rather than the bounty of plenitude, fortitude and democratic processes.

\section{Acknowledgements}

The author would like to acknowledge the frank and engaging comments he received from ACLALS New Zealand 2019 where he presented this article in draft form. He is specifically grateful to Prof. M.L. Hove for reading the draft and providing useful directions to improve the article.

\section{Competing interests}

The author has declared that no competing interests exist.

\section{Author's contributions}

The author alone contributed to this work. This article is partially based on the author's thesis for the degree of Master of Arts in English at the North-West University, Mafikeng Campus, South Africa, with supervisor Dr P. Ndlela, received October 2015, available at: http:/ /dspace.nwu.ac.za/bitstream/handle/ 10394/24935/Sibanda_S.pdf?isAllowed=y\&sequence=1.

\section{Ethical consideration}

This article followed all ethical standards for research without direct contact with human or animal subjects.

\section{Funding information}

This research received no specific grant from any funding agency in the public, commercial or not-for-profit sectors.

\section{Data availability statement}

Data sharing is not applicable to this article as no new data were created or analysed in this study. 


\section{Disclaimer}

The views and opinions expressed in this article are those of the author and do not necessarily reflect the official policy or position of any affiliated agency of the author.

\section{References}

Chan, S. \& Primorac, R., 2013, Zimbabwe in crisis: The international response and the space of silence, Routledge, London.

Chinodya, S., 1989, Harvest of thorns, Baobab Books, Harare.

Chirasha, B., 1991, (pen name of Chinodya), Child of war, Macmillan Publishers, Harare.

Chung, F., 2006, Re-living the second Chimurenga: Memories from Zimbabwe's liberation struggle, Elanders Gotab, Stockholm.

Darnolf, S. \& Laakso, L., 2003, Twenty years of independence in Zimbabwe: From liberation to authoritarianism, Palgrave MacMillan, New York, NY.

Driver, D. \& Samuelson, M., 2007, 'History's intimate invasions: Yvonne Vera's The stone virgins', English Studies in Africa 50(2), 101-120. https://doi.org/10.1080/ 00138390709485252

Gunner, L., 1991, 'Power, popular consciousness, and the fictions of war: Hove's Bones and Chinodya's Harvest of thorns', African Languages and Cultures 4(1), 77-85. https://doi.org/10.1080/09544169108717729

Hendricks, F., Ntsebeza, L. \& Helliker, K. 2013, The Promise of Land: Undoing a Century of Dispossession in South Africa, Jacana, Johannesburg.

Hochbruck, W., 1994, 'The changing colours of the enemy in Zimbabwean war fiction', Krieg und Literatur 6(1994), S131-S136.

Hove, C., 1988, Bones, Baobab, Harare.

Mapfumo, T., 2015, The Mugabe years, viewed 09 March 2015, from http://links.org. au/node/3232.

Marechera, D., 2009, The house of hunger, Heinemann, London.

Mda, Z., 2000, The heart of redness, Oxford University Press Southern Africa, Cape Town.
Mhanda, W., 2005, The struggle for Zimbabwe: Contesting the meaning of liberation, University of KwaZulu-Natal, KwaZulu-Natal.

Mudzingwa, K., 2003, 'Review of writing still: New stories from Zimbabwe', Business Tribune, p. 1, viewed 25 September 2013, from http://weaverpresszimbabwe. com/reviews/11-writing-still-new-stories-from-zimbabwe/160-review-of-writing$\mathrm{com} /$ reviews/11-writing-still-new-stories-from-zimbabwe
still-new-stories-from-zimbabwe-kamurai-mudzingwa.

Mungoshi, C., 1989, Waiting for the rain, Zimbabwe Publishing House, Harare.

Muponde, R. \& Primorac, R., 2005, Versions of Zimbabwe: New approaches to literature and culture, Weaver Press, Harare.

Mupondi, A., 2013, 'The marginalised in post-independence Zimbabwe in selected stories in Memory Chirere's short story anthology somewhere in this country', Journal for Studies in Humanities \& Social Sciences 2(2), 94-102.

Newsday Zimbabwe, 2014, Exam leaking taking a toll on education system, p. 1, viewed 10 November 2014, from https://www.zimbabwesituation.com/news/ zimsit-m-exam-leaking-taking-a-toll-on-education-system-newsday-zimbabwe/.

Nkomo, J.M., 1981, The new Zimbabwe, SAPES Books, Harare.

Norman, A., 2015, Robert Mugabe and the betrayal of Zimbabwe, McFarland, London. Onyeani, C., 2015, Roar of the African lion, Timbuktu Publishers, New York, NY.

Raftopoulos, B. 1994, Zimbabwe: Race and Colonialism in a Post Colonial State, IDS Research Paper, no 10. Harare.

Raftopoulos, B. \& Mlambo, A., 2011, 'Outside the Third Chimurenga: The challenges of writing a national history of Zimbabwe', Critical African Studies 4(6), 2-14 https://doi.org/10.1080/20407211.2011.10530763

Raftopoulos, B. \& Savage, T., 2004, Zimbabwe injustice and political reconciliation, Institute for Justice and Reconciliation, African Minds, Cape Town.

Randolph, R.H., 1985, Dawn in Zimbabwe, Mambo Press, Gweru.

Skuza, S., 1989, Love and scandal, Zimbabwe Music Corporation, Bulawayo.

Staunton, I., Postcolonial African literature: The experience of Zimbabwe (1) the seventeen-year Civil war and its immediate literary aftermath, viewed 23 April 2014 from http://www.postcolonialweb.org/zimbabwe/miscauthors/staunton1.html.

Veit-Wild, F., 1993, '“Dances with bones”: Hove's romanticized Africa', Research in African Literatures 24(3), 5-12.

Vera, Y., 2002, The stone virgins, Weaver Press, Harare. 